Musiy, R.Y., Midyana, G.G., Makitra, R.G., Vasyutin, J.M., Khovanets, G.I., and Zaborowskiy, A.B.

Department for Physics and Chemistry of Fossil Fuels of the Lytvynenko Institute for Physical Organic Chemistry and Coal Chemistry of NASU, Lviv

\title{
SOLAR THERMAL AIR COLLECTOR BASED ON A NEW TYPE OF SELECTIVE COATING
}

A solar thermal air collector operating on solar power on the principle of simultaneous ventilation and heating of facility has been designed on the basis of the best selective coating by optical characteristics and performance specifications. It can be used for holiday hotels, museums, wooden churches, warehouses, garages, houses, greenhouses, etc.

Key words: selective coating, sol-gel method, thermal solar air collector.

\section{APPLICABILITY OF THE PROBLEM}

Demand for cheap, efficient, and clean energy is growing rapidly. The use of natural gas and other traditional energy sources for heating of buildings in Ukraine is very expensive. Therefore, there appears a trend towards the environmentally friendly principles of life and use of solar energy. Solar energy is free, effective, and safe. It does not pollute the atmosphere with carbon dioxide. Extensive use of solar systems based on solar thermal collectors is constrained by high cost of such systems, which makes them unaffordable for majority of potential customers. However, currently, a significant rise in prices for energy and a sharp reduction of reserves have made it feasible to develop new designs of solar collectors with high performance specifications and significantly lower cost.

The solar thermal air collector is referred to the air heating and ventilation equipment operating entirely on solar radiation and is non-toxic

\footnotetext{
(C) MUSIY, R.Y., MIDYANA, G.G., MAKITRA, R.G., VASYUTIN, J.M., KHOVANETS, G.I.,

ZABOROWSKIY, A.B., 2014
}

and environmentally friendly. The collector blows fresh air into the house, removes moisture and stink, and reduces the risk of dry rot. The solar system is ideal for buildings dwelled from time to time. Having been installed the solar collector runs automatically, free, and all the year round.

\section{MATERIALS FOR SELECTIVE COATING}

The main structural element which affects the thermal efficiency of solar collector is heat absorbing surface. To increase the share of solar energy absorbed the special selective coatings with a high sunlight absorption coefficient $\alpha$ in the short-wave band and with a low radiating capacity $\varepsilon$ in the long-wave band are used. They are produced with the help of the cutting-edge and high-cost vacuum deposition techniques. However, there are problems related to the use of these coatings for majority of designs of solar collectors and their high cost. This makes the manufacture of Ukraine-made solar thermal collectors impossible.

The team of contributors has created a new type of selective coating with the use of carbonsilicon nanocomposites prepared by sol-gel meth- 
od [1-4]. The sol-gel method is a simple and easy way to obtain the materials having functional groups in superficial layer. This method provides ample opportunities for creating the materials and their surfaces with prescribed properties. This coating has a high factor of solar radiation absorption that is necessary for the efficient operation of solar collectors.

To achieve the selectivity it is necessary to apply a thin coating on a highly reflecting metallic substrate. The team of contributors has developed the spectrally selective composite coatings of carbon nanoparticles dispersed into dielectric matrices $\mathrm{SiO}_{2}$ and $\mathrm{NiO}$. Other researchers [5-7] have applied a similar selective coating with the use of mainly nickel or cobalt nanoparticles dispersed into $\mathrm{Al}_{2} \mathrm{O}_{3}$. The main drawback of this type of selective absorbers is connected with the fact that the metal particles are oxidized over time, especially, at high temperatures. Therefore, it is necessary to use the semi-metallic and nonmetallic nanoparticles with thermal stability within the temperature range from $-40{ }^{\circ} \mathrm{C}$ to $+250{ }^{\circ} \mathrm{C}$. For this reason, the contributors use the carbon nanoparticles. The selection of oxide matrices is explained by the need for the use of oxides with minimum infrared absorption. Both carbon and silicon are the widespread, environmentally friendly, and sustainable materials, especially, at high temperatures and high humidity, under which the solar collectors are operating. The carbon-silicon composite can be easily synthesized by the sol-gel technique. The proposed technique is cheap and effective. It facilitates control over the parameters of coatings, such as size of absorbing particles, their size distribution, homogeneity, and thickness.

To obtain the experimental models the sol-gel method based on tetraethoxysilane, methyltrimethoxysilane, and various organic and inorganic additives [8] has been used with temperature, concentration, viscosity, thickness, and other parameters being controlled. The coatings have been applied to aluminum and copper specimens of $40 \times 40 \mathrm{~mm}$ by spin coating method and watering of the plates with further drying at different temperatures. As a result of research, several types of selective coatings for solar collectors have been developed and produced by the sol-gel method. The initial comparative study of these coatings has been made with the use of a sample made by SunSelect (Germany). This sample is obtained by the vacuum deposition technique widely used abroad for the manufacture of solar collectors.

\section{STUDY OF THERMAL CHARACTERISTICS OF SELECTIVE COATINGS}

The aim of this research is to determine the most effective type of selective coating with respect to different options of its production. The effectiveness of solar energy absorption by the samples obtained has been estimated by different methods.

\section{Temperature measurement of samples during their irradiation by natural solar energy}

The coating samples obtained in the course of experiment should be estimated in many ways. When comparing the effectiveness of different types of selective coatings, one of such parameters can be the maximum heating temperature of coated plate irradiated by natural solar energy. For this purpose, there has been made a comparative study of the effectiveness of different types of coatings with respect to the reached equilibrium temperatures.

The results of measurements have showed the permanent deviation of equilibrium temperature of the one sample as compared with that of the other for various values of solar heat flux density [9]. The heating temperature of the best sample obtained by sol-gel method is almost identical to that of highly selective coating produced by SunSelect (Germany).

The method used eliminates almost all the errors related to temperature measurement. The measurements are performed simultaneously by all the thermocouples with further delivery of data to the multi-channel analog-to-digital converter. 


\section{Temperature measurements of samples irradiated by simulated solar radiation}

In addition, the coating has been tested with the help of comparing method with respect to heating by simulated continuous solar spectrum. The halogen lamps with filament temperature of about $2900{ }^{\circ} \mathrm{C}$ have been used as light source. In order to stabilize the luminous flux the simulating lamp has been fed through a constant voltage regulator, at $220 \mathrm{~V}$. The halogen lamp with aluminum reflector at the filament temperature $2900{ }^{\circ} \mathrm{C}$ has a continuous spectrum with maximum intensity at a wavelength of 0.90 microns versus 0.55 microns in the case of natural sunlight. Due to the continuity of both spectra the physical mechanisms of absorption of radiant energy for the Sun and the halogen incandescent lamps are virtually identical. Therefore, for the comparative studies the replacement of solar radiation by the artificial one with the equal integral intensity also does not significantly affect the mechanisms and regimes of energy transformations in irradiated samples [10,11].

Usually, the receiving surfaces of solar thermal collectors are coated with thin-film selective materials with a high absorption coefficient within the range of wavelength of the optical band of the solar spectrum, from 0.38 to 3.0 microns [12]. This range consisting of the visible and the infrared radiation has the share of about $98 \%$ of the solar radiant energy which penetrates the Earth's atmosphere and reaches the Earth's surface. To register the signals of measuring thermocouples a multi-channel regulator PT-0102 [1] produced by Termoprylad Research and Manufacturing Association has been used. It has the options of cross-automated measurement, archiving, regulation, and signaling. To measure the temperature of samples while they are irradiated by simulated sunlight a measuring installation consisting of optical, thermometric, recording, and controlling units has been created (Fig. 1).

The optical part includes a glow bulb and a diaphragm system of metering cell mounted on the optical bench, as well as auxiliary gauges: a pyra-

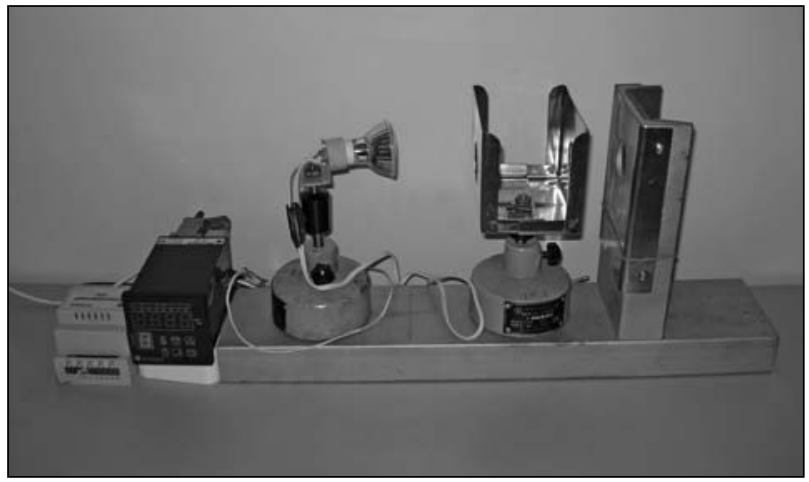

Fig. 1. Measuring installation

nometer M80m $(3 \times 3)$ and a portable actinometer Electronika IKIM-79 designed for calibration of the light beam by intensity and its cross-distribution. The thermometric part consists of thermocouple (type XA), the cold ends of which are led to the box of multichannel regulator PT-0102.

The information part consists of a computer connected via serial interface RS232 by a threewire line galvanically separated from other circuits. PT-0102 supports MODBUS protocol and gives all the parameters of regulation and archiving. The information and measuring parts are operated under the algorithm of licensed software TPara8, which allows the researchers to take data from the device visually or to archive them in a digital form or as graphic image and to change the settings of thermometric unit.

Several studies of many samples with selective coating obtained by the sol-gel method have been made with the help of the measuring installation. The mean temperature of samples irradiated by incandescent lamp with intensity $1000 \mathrm{~W} / \mathrm{m}^{2}$ is given in Table below. Thus, in all the cases, the reference sample SintSolar (Germany) has a higher equilibrium temperature than our samples. The difference is up to $25^{\circ} \mathrm{C}$ (for sample no. 8).

However, the equilibrium temperature of the sample no. 6 is virtually identical to that of the German-made reference sample (no.9). The observed difference is almost equal to the amplitude of random fluctuations of the reference sample temperature. Accordingly, the composition, me- 


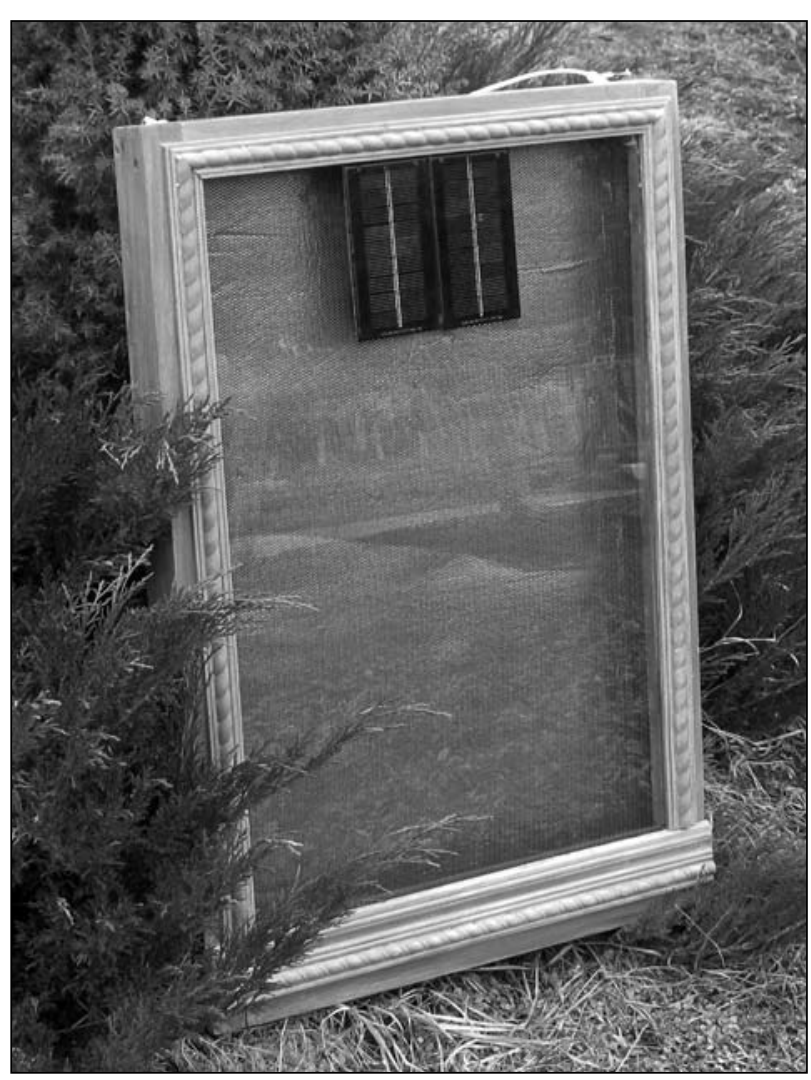

Fig. 2. General view of solar thermal air collector

thod of preparation, and application of sample no. 6 can be considered promising for further development. This sample can be used for manufacturing the solar collector's receiving panel which converts solar energy into heat.

\section{STUDY OF THERMAL CHARACTERISTICS OF SOLAR THERMAL COLLECTORS}

On the basis of the best selective coating with respect to optical and performance parameters a solar thermal air collector has been designed (Fig. 2 ). It works on the principle of simultaneous ven- tilation and heating. The collector consists of:

+ Sealed case;

+ Receiving panel with selective coating to convert solar energy into heat;

+ Solar photovoltaic module to generate the required voltage to be used for fan operation; and + Air supply system.

To study the thermal characteristics of solar thermal air collector a special test bench has been designed. It is made on a skeleton framework welded of metallic sections. For the sake of its easy use the bench is equipped with roller supports. On the front panel there are placed the elements of measuring equipment, control panel, and the bench's circuit. On the back panel (Fig. 3) there are located the fixing frame of air collector and the simulator of sunlight made of eight halogen spotlights each having a power of $500 \mathrm{~W}$. To control the parameters of radiation a pyranometer has been mounted. The power supply for the fan blowing through the air collector has been realized by a photoelectric panel (power $5 \mathrm{~W}$ ) installed under the collector's transparent cover. The photopanel is blown by a stream of incoming cold air which prevents its overheating and supplies electrical power for the fan operation in a stable manner.

The object of test is an air collector $(88 \times$ $\times 47.5 \mathrm{~cm}$ ) with transparent polycarbonate cover and light absorbing surface (see Fig. 2). Inside the collector, under its transparent cover, there is a small photovoltaic module to power to the fan providing uninterrupted supply of heat transfer agent. The results of comparison definitely give reason to believe that within the range of typical values of irradiance and operating temperatures the air collector characteristics are close to those of the industrial water collectors with selective

Results of comparative measurements of absorbing capacity of studied samples

\begin{tabular}{|l|c|c|c|c|c|c|c|c|c|c|c|}
\hline Sample studied & no. 1 & no. 2 & no. 3 & no. 4 & no. 5 & no. 6 & no. 7 & no. 8 & $\begin{array}{c}\text { Reference sample } \\
\text { SintSolar, no. } 9\end{array}$ & no. 10 & no. 11 \\
\hline Temperature, ${ }^{\circ} \mathrm{C}$ & 54.2 & 56.3 & 46.8 & 51.6 & 47.7 & 63.4 & 48.4 & 42.2 & 67.5 & 55.8 & 47.3 \\
\hline
\end{tabular}




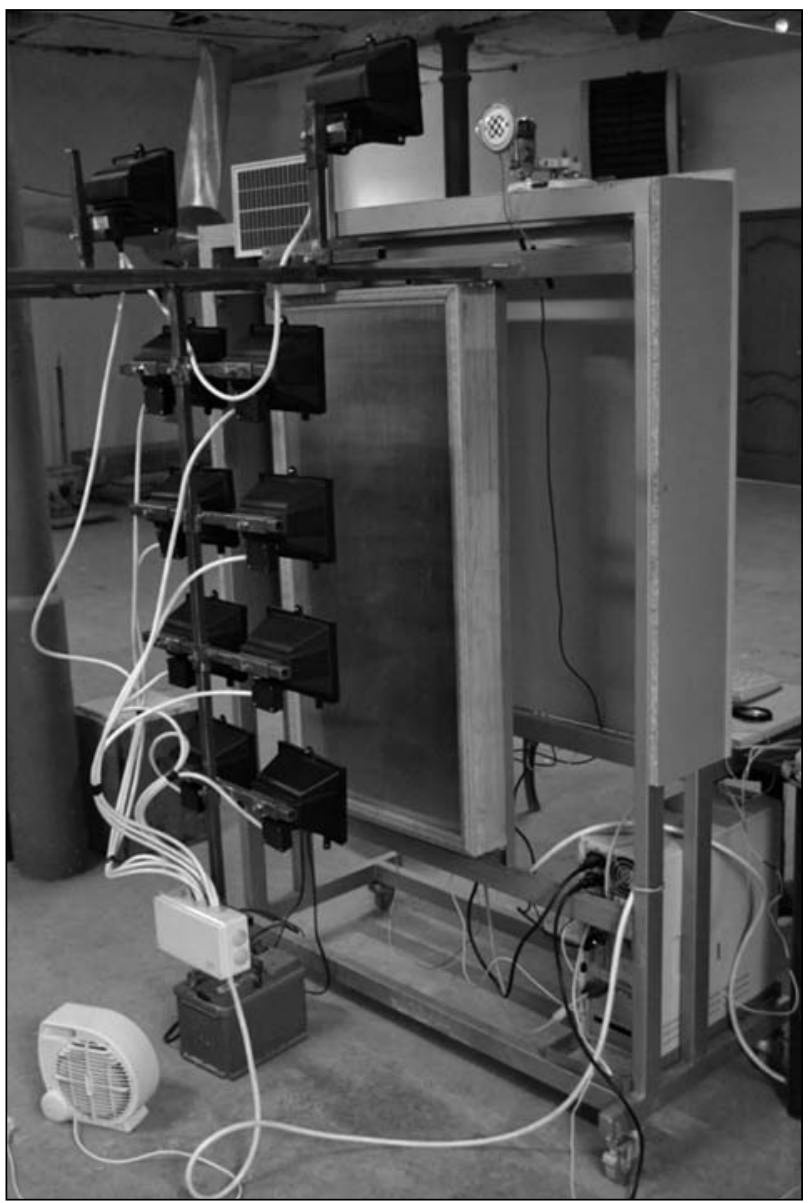

Fig. 3. Back panel of test bench for studing the heat characteristics of solar thermal air collector

coating of receiving surface. As a result of numerous experiments dealing with changing various parameters of solar air collectors it has been established that the maximum temperature of air supplied to the room is $70^{\circ} \mathrm{C}$.

\section{INSTALLATION OF SOLAR THERMAL AIR COLLECTORS}

The solar thermal air collectors have a wide scope of application in various industries. They can be used for villas, holiday homes, garages, warehouses, museums, wooden churches, greenhouses, etc. As a result of the project the solar thermal air collectors have been installed at the

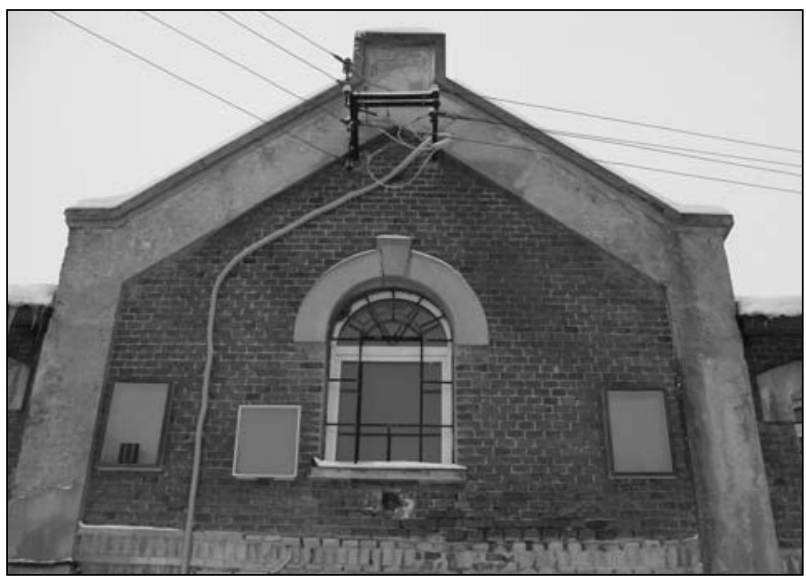

Fig. 4. Installation of solar thermal air collectors on building of the laboratory for renewable energy, Lviv National Agrarian University

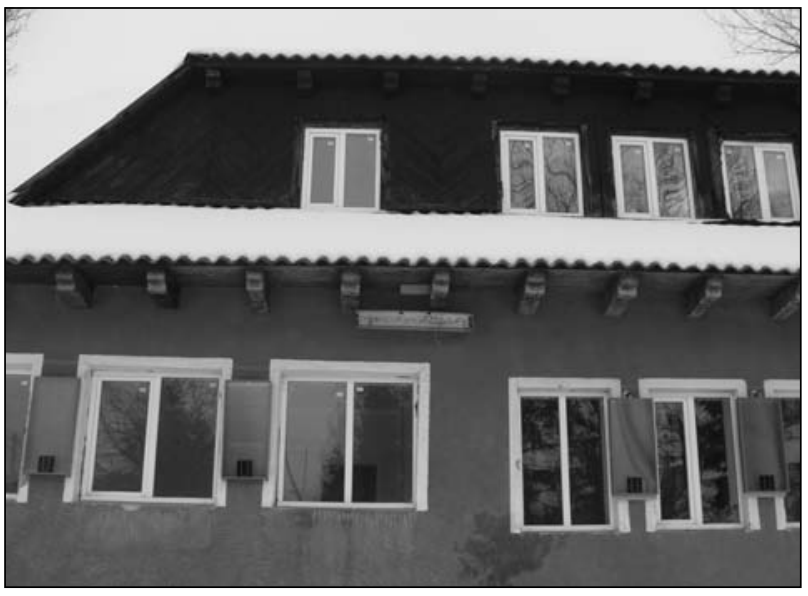

Fig. 5. Installation of solar thermal air collectors on the building of the Catechetical School (town of Deliatyn, Nadvirnianskyi Raion, Ivano-Frankivsk Oblast)

Laboratory for Renewable Energy of the Lviv National Agrarian University (Dubliany, Zhovkva Raion, Lviv Oblast (see Fig. 4). They are used for carrying out the long-lasting in vivo tests, making further improvement of collector's design and for training the specialists in the sphere of energy and electrical systems of agricultural complex and promotion of the use of renewable energy. These collectors have also been installed in the catechetical school (town of Deliatyn, Nadvirna Raion, Ivano-Frankivsk Oblast (see Fig. 5), 
a center of youth education in different directions where the youth spends its off-hour time.

The solar collectors installed on the above buildings lay foundation for the informational and educational activities which will help attract more stakeholders to the use of environmentally friendly technologies. The selected objects are demo centers for eco-technologies. In the future, the solar collectors will be made entirely of the Ukrainian raw and will be an integral component of the complex system of power supply to the economic entities with the use of renewable energy sources.

\section{CONCLUSIONS}

In the course of research the following results have been received:

1) The coating based on silicon-carbon nanocomposite has been obtained with the use of solgel technique;

2) The optical characteristics and performance specifications of selective coatings have been studied; the most effective selective coating has been identified with the use of a lamp solar simulator;

3) On the basis of the best selective coating with respect to its optical performance a solar thermal air collector has been designed;

4) The thermal characteristics and operational performance of solar thermal collectors have been studied with the help of specially designed test bench;

5) The solar thermal air collectors have been installed on two social objects.

\section{PROSPECTS FOR IMPLEMENTATION OF RESULTS}

On the basis of a new type of selective coating the innovative solutions related to developing various solar thermal air collectors can be made with respect to:

+ Modification of the shape and size of collectors;

+ Manufacture of new models of collectors for drying herbs, berries, and mushrooms.
Also, the following solar collectors with additional elements can be made:

+ Water collector to heat water and buildings;

+ Collectors with battery for backup power source;

+ Collectors with cooling option using underground air duct;

+ Collectors with the use of solar energy concentrators and sun tracking systems which largely increase the efficiency of the collectors.

The demand for the development and research of new absorbing coatings and solar thermal air collectors is determined by manufacturers of solar systems. In Ukraine, in the absence of government support of promoting the broad implementation of household heating and hot water supply systems it is necessary to establish production of solar thermal collectors running exclusively on solar energy and thereby to fill the vacant segment of solar engineering.

The energy resources based on environmentally friendly non-toxic materials and not polluting the atmosphere are nowadays of paramount importance. The use of solar energy becomes a reality proven by continual practice. In view of high cost of traditional forms of energy and steady reduction of energy reserves there is no alternative to the renewable energy sources.

\section{REFERENCES}

1. Gusev, A.I. (2007). Nanomaterials, Nanostructures, Nanotechnology. Moscow: Nauka-Fizmathiz (in Russian).

2. Shyilova, O.A. and Shylov, V.V. Oxide Nanocomposite and Hybrid Organic-Inorganic Materials Prepared By Sol-Gel Method. Synthesis. Properties. Application. $\mathrm{Na}$ nosystems, Nanomaterials, Nanotechnologies, 1, 1, 9-83 (2003) (in Russian).

3. Zhifeng, Liu, Zhengguo, Jin, Wei, Li, and Jijun, Qiu Preparation of $\mathrm{ZnO}$ Porous Thin Films by Sol-Gel Method Using PEG Template. Materials Letters, 59, 3620-3625 (2005).

4. Armelao, L., Fabrizio, M., Gialanella, S. and Zordan, F. Sol-gel Synthesis and Characterization of $\mathrm{ZnO}$-Based Nanosystems. Thin Solid Films, 394, 90-96 (2001).

5. Morris, C., Rolison, D., Swider-Lyons, K., Osburn-Atkinson, E. and Merzbacher, C. Modifying Nanoscale Silica with Itself: a Method to Control Surface Properties 
Silica Aerogels Independently of Bulk Structure. Journal of Non-Crystalline Solids, 285, 29-36 (2001).

6. Mwamburi, M., Hoel, A., and Wackelgard, E. Surface Morphologies of Spectrally Selective and PolarizationDependent Angular Optical Reflectors of SnOx: FCoated Anodized Aluminium. Solar Energy Materials $\mathcal{E}$ Solar Cells, 84, 1-4, 381-394 (2004).

7. Bostroem, T., Westin, G., and Waeckelgard, E. Optimization of a Solution-Chemically Derived Solar Absorbing Spectrally Selective Surface. Solar Energy Materials E Solar Cells, 91, 1, 38-43 (2007).

8. Musiy, R., Khayrnasov, S., Zinchenko, A. and Semenyuk, I. Investigation of Selective Coatings via the Method of Sol-Gel Technology for Solar Collectors. International Symposium on the 80th Anniversary of Academician O.O. Chuiko «Modern Problems of Surface Chemistry and Physics» Kyiv (Ukraine), 318-319 (2010).

9. Musiy, R.I., Khovanets, G.I., Hayrnasov, S.M., et al. Organic-Inorganic Sol-Gel Composites for Solar Selective Coatings. International Conference «Sol-Gel Synthesis and Study of Inorganic Compounds, Hybrid Functional Materials and Disperse Systems Sol-Gel-2012» Sevastopol (Ukraine), 59 (2012) (in Russian).

10. Simulation of Thermal Modes of the Spacecraft and the Environment. In Petrov, G.I. (ed.), Moscow: Mechanical Engineering, (1971) (in Russian).

11. Vugman, S.M. and Volkov, V.I. (1980). Halogen Lamps. Moscow: Energia (in Russian).

12. Duffie, J. and Beckman, W.A. (1987). Solar Engineering of Thermal Processes. Moscow: Mir (in Russian).
Р.Й. Мусій, Г.Г. Мідяна, Р.Г. Макітра,

Я.М. Васютин, Г.І. Хованещь, А.Б. Заборовський

СОНЯЧНИЙ ТЕПЛОВИЙ ПОВІТРЯНИЙ

КОЛЕКТОР НА ОСНОВІ НОВОГО ТИПУ

СЕЛЕКТИВНОГО ПОКРИТТЯ

На основі найкращого селективного покриття за оптичними та експлуатаційними характеристиками сконструйовано сонячний тепловий повітряний колектор, що працює виключно від сонячної енергії за принципом одночасної вентиляції приміщення та обігріву. Його можна застосовувати для будинків відпочинку, музеїв, дерев'яних церков, складів, гаражів, дач, теплиць і т.п.

Ключові слова: селективне покриття, золь-гель метод, сонячний тепловий повітряний колектор.

Р.И. Мусий, Г.Г. Мидяна, Р.Г. Макитра, Я.М. Васютин, Г.И. Хованец, А.Б. Заборовский

СОЛНЕЧНЫЙ ТЕПЛОВОЙ ВОЗДУШНЫЙ КОЛЛЕКТОР НА ОСНОВЕ НОВОГО ТИПА СЕЛЕКТИВНОГО ПОКРЫТИЯ

На основе лучшего селективного покрытия по оптическим и эксплуатационным характеристикам сконструирован солнечный тепловой воздушный коллектор, работающий исключительно от солнечной энергии по принципу одновременной вентиляции помещения и обогрева. Его можно применять для домов отдыха, музеев, деревянных церквей, складов, гаражей, дач, теплиц и т.д.

Ключевые слова: селективное покрытие, золь-гель метод, солнечный тепловой воздушный коллектор.

The paper was received on 20.06 .13 